\title{
Combining Ability for Resistance to Sweetpotato Feathery Mottle Virus
}

\author{
Elisa Mihovilovich ${ }^{1}$, Humberto A. Mendoza ${ }^{2}$ and Luis F. Salazar ${ }^{3}$ \\ Department of Crop Improvement and Genetic Resources, International \\ Potato Center (CIP), Box 1558, Lima, Peru
}

Additional index words. Ipomoea batatas, general combining ability, specific combining ability, diallel mating design, additive gene action

\begin{abstract}
Combining ability for resistance to Sweetpotato Feathery Mottle Virus (SPFMV) was evaluated in seven sweetpotato [Ipomoea batatas (L.) Lam] clones. A diallel mating design was used, which resulted in $\mathbf{1 6}$ full-sib families. Families were evaluated for SPFMV resistance under greenhouse conditions in a randomized complete-block design. Resistance was tested by grafting Ipomoea nil 'Scarlet $O$ ' Hara' infected with the russet crack strain of SPFMV (RC-SPFMV) onto individual plants of the families being evaluated. Symptomless plants were further indexed by cleft grafting virus-free Ipomoea setosa Ker plants onto the tested plants. Those plants in which the virus was not recovered by this test were considered resistant. Analysis of variance for SPFMV resistance revealed significant general combining abilities (GCA). Two clones, DLP-886 and TN90.300, exhibited significant positive GCA for SPFMV resistance. No significant specific combining abilities (SCA) were detected among the crosses. Breeding for resistance to SPFMV should focus on careful selection of resistant parents. In addition, results suggest that additive gene action is important in resistance to SPFMV.
\end{abstract}

Sweetpotato Feathery Mottle Virus ${ }^{\mathrm{TM}}$ (SPFMV) is distributed worldwide and is considered to be the most serious viral disease of sweetpotato (Clark and Moyer, 1988). Although it can be transmitted by aphids, the most important means of spread is the use of infected plants (Terry, 1981). Yields are gradually reduced as time progresses because of recurrent use of infected vines in propagation. The virus has been reported to interact synergistically with a whitefly-transmitted agent, causing yield reductions of up to $80 \%$ in fresh storage roots (Clark and Moyer, 1988). The development of virus-resistant cultivars would be the most effective means to overcome this yield constraint. Two types of SPFMV resistance have been identified in SPFMV-infected sweetpotato plants: 1) genotypes that contain the virus, but do not show symptoms; and 2) those that do not show symptoms and do not transmit the virus upon grafting to virus free-indicator plants (Nielsen and Pope, 1960). The latter expression is the more desirable because resistant cultivars are not a source of inoculum. This type of resistance has been identified in some sweetpotato accessions of the Sweetpotato Germplasm

\footnotetext{
Received for publication 7 Sept. 1999. Accepted for publication 8 May 2000. We thank George C.C. Tai for the support on the genetic and statistical analyses of the data. The cost of publishing this paper was defrayed in part by the payment of page charges. Under postal regulations, this paper therefore must be hereby marked advertisement solely to indicate this fact.

${ }^{1}$ Graduate Student. E-mail address: e.mihovilovich@ cgiar.org

${ }^{2}$ Senior Geneticist.

${ }^{3}$ Senior Virologist. Pathology Dept., International
} Potato Center (CIP).
Collection held in trust at the International Potato Center (CIP) (1990). However, incorporation of this resistance into breeding populations has not been achieved. The lack of knowledge about the inheritance of this resistance is one of the factors that hinders its use. The objectives of this study were to evaluate the resistance to SPFMV among families derived from a sample of CIP's sweetpotato accessions in a diallel mating design, in order to estimate combining ability for SPFMV resistance. This will allow the identification of parental clones and selection methods to introduce SPFMV resistance into advanced breeding populations.

\section{Materials and Methods}

Seven sweetpotato clones from CIP's germplasm collection were used as parents in a diallel mating design (Model I, Method 4) of Griffing (1956). Three of these clones were taken at random from a group of 13 accessions identified as resistant to several strains of SPFMV distinguished by host range and symptom expression in sweetpotato plants (CIP, 1990). The other four were selected based on flowering performance and SPFMV susceptibility. Susceptibility in these clones was first determined by visual foliar symptoms of SPFMV in the field and then confirmed by enzyme-linked immunosorbent assay (ELISA) test. Twenty-one crosses were made, but only 16 families were generated because of incompatibilities between certain crosses.

Families were evaluated for SPFMV resistance under greenhouse conditions during the summer in Lima, Peru. The experiment was conducted in a randomized completeblock design with three replications. Each replication consisted of 40 individuals of each of the 16 families. Acid-scarified seeds were germinated in Jiffy 7 single STD-700 (Jiffy Products, N.B., Canada). Seedlings with three or four internodes were transplanted into 30.5 -cm-diameter plastic pots, containing a mixture of 1 soil : 1 sand : 1 peat (by volume). Virus inoculation was carried out 1 month after transplanting by grafting scions of Ipomoea nil, which had been previously mechanically inoculated with the russet crack strain of SPFMV (RC-SPFMV), onto individual sweet potato plants of the families being tested. The virus isolate used for inoculation was provided by Dr. James Moyer of North Carolina State Univ., Raleigh. Three evaluations of foliar symptoms on sweetpotato plants were conducted at 4-d intervals, beginning $20 \mathrm{~d}$ after grafting. Foliar symptoms characteristic of SPFMV infection, such as veinbanding and chlorotic and purple ring spots (Clark and Moyer, 1988), were scored as present or absent. SPFMV in symptomatic plants was confirmed by NCM-ELISA serological test (Abad and Moyer, 1992). Symptomless plants were then indexed. Two stem cuttings of each symptomless plant were planted in $15.2-\mathrm{cm}$ plastic pots. Virus-free Ipomoea setosa plants were cleft-grafted onto symptomless sweetpotato plants $20 \mathrm{~d}$ after planting. After another $20 \mathrm{~d}$, foliar symptom expression on I. setosa scions was evaluated based on presence or absence of the previously described symptoms. Presence of SPFMV in I. setosa scions of symptomless infected plants was confirmed by NCMELISA serological test. Those symptomless plants, in which the virus was not recovered in I setosa scions, were considered resistant. Data were collected on a plot basis within each replication. Because of losses of some plants during the trial, percentage of resistant individuals was calculated on unequal numbers of observations per replicate. Arcsin transformation was used before statistical analysis according to Griffing's Model I (fixed parents), Method 4, (Griffing, 1956). Analysis of variance (ANOVA) took into account unequal numbers of progenies per family by weighting the sum of squares over the number of plants assessed in each family. The same was done to calculate general combining ability sum of squares, and specific combining ability was obtained by difference. General combining abilities (GCA)were estimated on the basis of the number of crosses in which each parent was involved. The computer program for the analysis was written in BASIC language by Dr. G.C.C. Tai, Agriculture Canada, Fredericton, N.B., Canada (personal communication).

\section{Results and Discussion}

The percentage of SPFMV-resistant plants in the 16 families ranged from 39 to 88 (Table 1). ANOVA for percentage of SPFMV resistance showed significant differences among families $(P \leq 0.01)$ and nonsignificant differences among replications. Partitioning of the family variation revealed significant GCAs $(P \leq 0.01)$; specific combining abilities were 
Table 1. Mean percentages \pm SE of RC-SPFMV-resistant plants in 16 sweetpotato families generated in a diallel mating design among resistant and susceptible parents.

\begin{tabular}{|c|c|c|c|c|c|c|}
\hline Parents $^{2}$ & $\begin{array}{c}\text { RCB-IN238 } \\
\text { (S) }\end{array}$ & $\begin{array}{c}\text { ARB-9996 } \\
\text { (S) }\end{array}$ & $\begin{array}{l}\text { DLP-2247 } \\
\text { (S) }\end{array}$ & $\begin{array}{c}\text { DLP-886 } \\
\text { (R) }\end{array}$ & $\begin{array}{l}\text { DLP-1913 } \\
(\mathrm{R})\end{array}$ & $\begin{array}{c}\text { TN90.300 } \\
(\mathrm{R})\end{array}$ \\
\hline YM88.030 (S) & $38.8 \pm 2.7$ & $42.2 \pm 6.9$ & $40.4 \pm 2.0$ & $68.8 \pm 10.3$ & $43.9 \pm 6.9$ & $70.7 \pm 8.7$ \\
\hline RCB-IN238 (S) & & $(-)^{y}$ & $49.5 \pm 13.2$ & $69.6 \pm 12.9$ & $46.9 \pm 8.0$ & $(-)$ \\
\hline ARB-9996 (S) & & & $42.2 \pm 11.3$ & $61.3 \pm 4.4$ & $64.2 \pm 1.9$ & $(-)$ \\
\hline DLP-2247 (S) & & & & $80.8 \pm 4.7$ & $69.4 \pm 10.1$ & $(-)$ \\
\hline DLP-886 & & & & & $(-)$ & $87.9 \pm 5.3$ \\
\hline DLP-1913 (R) & & & & & & $82.4 \pm 3.3$ \\
\hline TN90.300 (R) & & & & & & \\
\hline
\end{tabular}

${ }^{\mathrm{2}} \mathrm{R}=$ resistant, $\mathrm{S}=$ susceptible.

$\mathrm{y}_{-}=$incompatible.

Table 2. Estimates of the general combining ability (GCA) and SE for resistance to RC-SPFMV of seven sweetpotato parental clones. ${ }^{2}$

\begin{tabular}{lcc}
\hline \hline Parents & GCA & SE \\
\hline YM88.030 & $-7.2^{* *}$ & 1.9 \\
RCB-IN238 & $-7.0^{* *}$ & 2.4 \\
ARB-9996 & $-6.3^{*}$ & 2.4 \\
DLP-2247 & -1.1 & 2.1 \\
DLP-886 & $11.0^{* *}$ & 2.2 \\
DLP-1913 & 2.8 & 2.2 \\
TN90.300 & $10.4^{* *}$ & 2.8 \\
\hline
\end{tabular}

${ }^{2}$ Estimates for arcsin transformed data from Table 1.

${ }^{*, * * *}$ Significant at $P \leq 0.05$ and 0.01 , respectively.

nonsignificant. This result suggests that the frequency of resistance among offspring depended primarily on the parents instead of their specific combinations or interactions. Since the trial was conducted in one environment, environment $\times$ genotype effects would be confounded in these estimates.

Resistant parental clones DLP-886 and TN90.300 exhibited significant positive GCA for SPFMV resistance (Table 2), and their families gave high frequencies of SPFMVresistant progenies $(>60 \%)$ (Table 1$)$. The fam- ily generated by mating these two resistant parents gave the highest frequency of resistant progenies (88\%). Nielsen and Pope (1960) obtained a high proportion of resistant progenies from selfing a SPFMV-resistant clone and suggested that a high proportion of resistant progenies would result from crossing resistant clones. Clone DLP-1913 was resistant but showed nonsignificant GCA for resistance (Table 2). Three of the four susceptible parental clones (YM88.030, RCB-IN-238, and ARB-9996) showed significant negative GCA effects. In light of the differential ability of resistant clones to transmit their resistance, progeny tests should be used to identify superior parents for resistance to this pathogen. Screening of populations should discard susceptible genotypes. A screening method using mechanical inoculation of sweetpotato seedlings has been developed by Arrendell and Collins (1986). Since asymptomatic genotypes are common, it is advisable to index asymptomatic clones by graft inoculation onto healthy Ipomoea setosa.

Estimates of specific combining abilities of the 16 combinations were nonsignificant $(P>0.05)$, indicating that resistance to SPFMV might be predominantly controlled by additive gene effects. Fraser (1986) pointed out that in cases where virus resistance was con- trolled by more than one locus, additive effects were found. The level of resistance to SPFMV observed in this material has been reported by other researchers, who proposed that resistance limited multiplication or translocation of the virus so that it could not be recovered by graft indexing (Arrendell et al., 1986). Intermediate resistance levels may exist, but are difficult to identify because current techniques do not quantify SPFMV infection. This is not a serious limitation to developing an improvement program for SPFMV resistance, since careful selection of resistant parents with good combining abilities will allow achievement of this goal.

\section{Literature Cited}

Abad, J.A. and J.W. Moyer. 1992. Detection and distribution of sweetpotato feathery mottle virus in sweetpotato by in-vitro-transmitted RNA probes (Riboprobes), membrane immunobinding assay and direct blotting. Phytopathology 82:300-305.

Arrendell, S. and W.W. Collins. 1986. Reaction of sweetpotato seedlings to the russet crack strain of feathery mottle virus. HortScience 21:1191-1193.

Clark, C.A. and J.W. Moyer. 1988. Compendium of sweet potato diseases. Amer. Phytopath. Soc. Press, St. Paul, Minn. p. 74.

Fraser, R.S.S. 1986. Genes for resistance to plant viruses, p. 257-293. In: B.V. Conger (ed.). CRC Critical Rev. in Plant Sci., Vol. 3. CRC Press, Boca Raton, Fla.

Griffing, B. 1956. Concept of general and specific combining ability in relation to diallel crossing systems. Aust. J. Biol. Sci. 9:463-469.

International Potato Center (CIP). 1990. Annu Rpt. CIP 1990. Lima, Peru.

Nielsen, L.W. and D.T. Pope. 1960. Resistance in sweetpotato to the internal cork virus. Plant Dis. Rptr. 44:342-347.

Terry, E.R. 1981. Sweetpotato (Ipomoea batatas) virus diseases and their control, p. 161-168. In: R.L. Villareal and T.D. Griggs (eds.). Sweetpotato. Proc. First Intl. Symp. Asian Veg. Res. and Dev. Ctr. AVRDC Press, Taiwan, Republic of China. 